NBER WORKING PAPER SERIES

\title{
CAN RE-ENROLLMENT CAMPAIGNS HELP DROPOUTS RETURN TO COLLEGE? EVIDENCE FROM FLORIDA COMMUNITY COLLEGES
}

\author{
Justin C. Ortagus \\ Melvin J. Tanner \\ Isaac McFarlin Jr. \\ Working Paper 26649 \\ http://www.nber.org/papers/w26649 \\ NATIONAL BUREAU OF ECONOMIC RESEARCH \\ 1050 Massachusetts Avenue \\ Cambridge, MA 02138 \\ January 2020
}

This study is supported by a research grant from the Helios Education Foundation. We thank Peter Bergman, Angela Boatman, Joshua Hyman, and Dennis Kramer for their detailed feedback. We also thank conference participants at the Association for the Study of Higher Education for their helpful comments and Maryanne Long and Jiayao Wu for outstanding research assistance. The study was approved by the University of Florida Institutional Review Board (IRB201602705). The views expressed herein are those of the author and do not necessarily reflect the views of the National Bureau of Economic Research.

NBER working papers are circulated for discussion and comment purposes. They have not been peer-reviewed or been subject to the review by the NBER Board of Directors that accompanies official NBER publications.

(C) 2020 by Justin C. Ortagus, Melvin J. Tanner, and Isaac McFarlin Jr.. All rights reserved. Short sections of text, not to exceed two paragraphs, may be quoted without explicit permission provided that full credit, including $\odot$ notice, is given to the source. 
Can Re-Enrollment Campaigns Help Dropouts Return to College? Evidence from Florida

Community Colleges

Justin C. Ortagus, Melvin J. Tanner, and Isaac McFarlin Jr.

NBER Working Paper No. 26649

January 2020

JEL No. I2

\begin{abstract}
Most students who begin at a community college leave without earning a degree. Given the growing emphasis on student success, many colleges have implemented re-enrollment campaigns designed to foster re-engagement and degree completion among former students. However, there is a lack of causal evidence on their effectiveness. We implement a text message-based reenrollment campaign in partnership with several Florida community colleges. Former students who were previously successful academically are randomly assigned to one of two treatment groups that either receives information to simplify the re-enrollment process or receives both information and a one-course tuition waiver. When comparing outcomes of former students who received information on re-enrollment to members in the control group, we find that providing information that simplifies the re-enrollment process has a small, statistically insignificant effect on re-enrolling. In contrast, offering both information and a one-course tuition waiver to recent dropouts significantly increases the likelihood of re-enrollment by 1.5 percentage points (21 percent) and full-time re-enrollment by 0.6 percentage points ( 22 percent). The effects are concentrated among former students who have accumulated the most credits and those with lower grade point averages. This study highlights the importance of targeted interventions that address informational and financial barriers facing former students.
\end{abstract}

Justin C. Ortagus

College of Education

University of Florida

2-230C Norman Hall PO Box 117049

Gainesville, FL 32611

jortagus@coe.ufl.edu

Melvin J. Tanner

College of Education

University of Florida

2-230C Norman Hall PO Box 117049

Gainesville, FL 32611

melvinjtanner@ufl.edu
Isaac McFarlin Jr.

College of Education

University of Florida

2-230D Norman Hall

P.O. Box 117049

Gainesville, FL 32611

and NBER

imcfar@ufl.edu 


\section{Introduction}

As open-access institutions with diverse student bodies, community colleges provide access to higher education for a disproportionate number of underserved students (Bailey et al, 2015). For community college students who complete their degree, college can be economically rewarding (Belfield \& Bailey, 2011; Jepsen et al, 2014) and can also confer non-economic benefits, including improved health, longer life expectancy, and lower rates of incarceration (Trostel \& Chase, 2015). However, the majority of students who begin at a community college do not earn a degree (Baum et al, 2016; Snyder et al, 2018). Disparities in college dropout rates across demographic groups are especially worrisome, with Black and Hispanic students completing college at significantly lower rates than their white peers (Juszkiewicz, 2016; Shapiro et al., 2017). ${ }^{1}$

Despite the well-established benefits of obtaining a college degree, 36 million Americans have obtained some postsecondary education without completing a degree. Roughly 10 percent of these noncompleters have already made substantial academic progress toward earning a degree and are most likely, among former students, to re-enroll and graduate from college (Shapiro et al, 2019). In light of stagnant enrollments, declining state appropriations, and a renewed emphasis on student success, many colleges have launched re-enrollment campaigns targeted at former students who have made considerable progress toward obtaining a degree (Schwartz, 2019). To encourage re-enrollment, colleges reach out to former students by sending a combination of letters, emails, and text messages. In addition to using a variety of modalities of communication, colleges sometimes offer targeted scholarships to incentivize re-enrollment among former students. Although the number of re-enrollment campaigns in higher education has grown considerably in recent years, there is a lack of causal evidence on their effectiveness.

In this paper, we conduct a randomized controlled trial to evaluate the effect of text message-based interventions on re-enrollment behavior among previously successful former students at five high-enrollment community colleges. In partnership with participating community colleges, we sent multiple text messages

\footnotetext{
${ }^{1}$ We use the term "dropout" throughout this paper for the purpose of clarity, but students who withdraw from college on a temporary basis are often described as "stop-outs" rather than dropouts. 
to former students who had already made considerable progress toward their degree but were not currently enrolled at any postsecondary institution. More than 27,000 former students comprise our sample and are randomly assigned to receive one of two interventions through text messaging.

The first intervention consists of multiple text messages that provide information on how to re-enroll at the student's prior institution and a direct link to do so. In essence, the texts simplify and streamline the reenrollment process by providing embedded links to a website that informs the student how to re-enroll and apply for financial aid. Furthermore, the texts inform students of critical enrollment deadlines. The second intervention is similar to the first intervention but also offers a tuition waiver that covers the actual cost of enrolling in their first course. Former students who are randomly assigned to a control group do not receive any texts and, thus, are not offered a one-course tuition waiver or information that might facilitate reenrollment.

The rationale for developing these interventions rests on the theory of human capital and models of behavioral economics. On one hand, human capital theory implies that former students are rational actors when making decisions about continuing their education based on the costs and benefits associated with reenrollment (Mincer, 1958). Therefore, offering students one-course tuition waivers lowers near-term costs of financing a college education and may incentivize re-enrollment. On the other hand, the central motivation behind behavioral economics rests on the assumption that individuals have limited information and their decision-making can vary on the margins when decisions are complex, risky, or uncertain (Meyer \& Rosinger, 2019; Karlan, McConnell, Mullainathan, \& Zinman, 2016; Thaler \& Benartzi, 2004). Due to the perceived challenges associated with making complex decisions, former students may be inattentive to critical deadlines or deterred in carefully evaluating the costs and benefits of re-enrolling. Accordingly, they may avoid taking any action altogether. Because our interventions provide timely reminders and information that simplifies the re-enrollment process, treated individuals may be more likely to re-enroll.

Overall, we find no relationship between providing former students informational nudges, alone, and their likelihood of re-enrollment. However, we do find positive effects on the likelihood of former students 
re-enrolling when informational nudges are combined with a one-course tuition waiver. More specifically, former students who received both the information and one-course waiver are 1.5 percentage points (or 21 percent) more likely to return to college. The effects of the informational nudges combined with a course waiver are especially strong among former students who have lower GPAs, earned a substantial number of credit hours when previously enrolled, and students who are older than traditional undergraduates.

Our study makes two important contributions. Most obviously, this research sheds light on the efficacy of types of outreach campaigns aimed at fostering re-enrollment among former students. Despite the growing popularity of these targeted outreach programs (Schwartz, 2019), little is known regarding whether these targeted outreach programs are actually effective. As such, our study provides the first causal evidence that outreach campaigns can help former students return to college. Second, there is a nascent body of evidence that shows informational nudges alone do not significantly improve college enrollment or students' academic outcomes (Bettinger, Long, Oreopoulos, \& Sanbonmatsu, 2012; Bird, Castleman, Denning, Goodman, Lamberton, \& Rosinger, 2019; Oreopoulos \& Petronijevic, 2019). Our experimental findings align with this prior work by showing that informational nudges alone do not improve the likelihood of former students re-enrolling in college. However, our study provides compelling and robust evidence that combining informational nudges with a financial incentive improves the likelihood that former students return to college.

The remainder of the paper is organized as follows. Section II reviews prior literature on student attrition at community colleges and the effects of nudges and financial incentives on access and success in higher education. Section III outlines the data, sample, design of the intervention, mechanics of the randomization, and analytic strategy. Section IV presents our results, including both main and heterogeneous effects. Section V offers a discussion of the implications of our findings for practice, policy, and future scholarship.

\section{Literature Review}

Community colleges play a democratizing role for millions of underserved students (Belfield \& Bailey, 2011; Rouse, 1995), but many community college students leave college without completing a degree 
(Snyder, de Brey, \& Dillow, 2018). Approximately $47 \%$ of students who begin at a community college are no longer enrolled at any college or university, and only $38 \%$ of community college students complete their associate or bachelor's degree within six years of initial enrollment (Juszkiewicz, 2016; Shapiro et al., 2017). Prior literature has shown that many college students are unable to complete a degree due to informational and financial barriers that are unrelated to their academic ability or prior performance in coursework (Long, 2007). ${ }^{2}$

\section{A. Institutional Responses to Student Attrition}

Given widespread concerns that not enough qualified students reap the benefits associated with completing college, the federal government invests over $\$ 120$ billion each year to various initiatives designed to encourage college enrollment and graduation (Scott-Clayton, 2017). Many public colleges and universities, especially those whose funding is tied to institutional performance measures, invest considerable resources toward improving their retention and completion rates. In recent years, targeted initiatives have expanded beyond improving the outcomes of current students by seeking to help former students in good academic standing return to college and finish their degree.

Former students who left college before earning their degree have reported that they did not understand what was required to be able to re-enroll and lacked a clear list of next steps and specific deadlines related to the re-enrollment process (Inside Track, 2019). Behavioral nudges can be used as a mechanism to remove informational barriers for individuals who may not be attentive to or aware of critical information or deadlines related to how to return to college (Bird et al., 2019). In an effort to encourage recent noncompleters to return to college, numerous colleges have enacted re-enrollment campaigns to increase enrollment and completion numbers (Schwartz, 2019). For example, the University of Memphis created a reenrollment initiative targeted at students who stopped enrolling in courses at least a semester ago, have a 2.0

\footnotetext{
${ }^{2}$ Most research examining why students leave college is correlational. For example, Crosta (2013) highlights student attributes associated with the decision to drop out and finds community college dropouts are more likely to be older and less likely to receive financial aid. Additional work shows that students often leave college due to many financial issues unrelated to their ability to succeed in the classroom (e.g., Rath et al., 2013; Stinebrickner \& Stinebrickner, 2008). 
GPA, and earned 90 or more credit hours through their previous coursework (University of Memphis Finish Line Program, 2019). In addition, Waubonsee Community College (WCC) recently implemented a reenrollment campaign in which students received a postcard or phone call offering information about reenrolling, but the former students who were contacted via postcards or phone calls did not re-enroll at a higher rate than those students who were not contacted through the campaign (Lashure, Randall, \& Hinkle, 2019).

\section{B. Prior Evidence on Interventions to Increase Enrollment}

Numerous studies have employed informational interventions to determine the effect of nudges on the behaviors of both prospective and current college students. Castleman and Page (2015) found that their text messaging campaign had a positive impact on whether recent high school graduates enrolled in college. Additional work has shown positive effects associated with the implementation of text messaging programs on financial aid renewal among college freshmen (Castleman \& Page, 2016).

Some prior research has revealed positive effects of informational nudges on prospective students' likelihood of enrolling in college (Barr \& Turner, 2018; Castleman \& Page, 2015; Castleman, Page, \& Schooley, 2014; Page \& Gehlbach, 2017). Castleman, Owen, and Page (2015) found that contacting high school graduates via phone, email, and text messaging increased the likelihood of college enrollment among Hispanic males. Hyman (2019) mailed letters encouraging high-achieving high school seniors to consider college and engage with a custom website containing additional information. The author reported that lowincome students were more likely to attend college after receiving the informational letters, but the results appeared to be driven by low-income student enrollment at four-year institutions.

Several researchers have sent emails or mailed letters to describe the benefits of college to prospective college students and found no effect on the likelihood of enrollment (Bergman, Denning, \& Manoli, 2019; Gurantz, Howell, Hurwitz, Larson, Pender, \& White, 2019; Kerr, Pekkarinen, Sarvimäki, \& Uusitalo, 2014). Bettinger et al. (2012) found no change in college enrollment in response to a treatment offering financial aid information, but an additional treatment offering both financial aid information and professional assistance 
completing the FAFSA led to an increase in enrollment among dependent students and independent students with no prior college experience.

In a recent study examining the efficacy of nudge interventions at scale, Bird, Castleman, Denning, Goodman, Lamberton, and Rosinger (2019) employed a state-level and nationwide campaign that reached over 800,000 students, finding no impact of their information-based nudging campaign on the likelihood of college enrollment for any student subgroups. Oreopoulos and Petronijevic (2019) designed online and textmessage interventions in order to improve student achievement in college and found no effect on college students' academic outcomes - even among those students who were identified as more likely to drop out of college. According to a systematic review of experimental and quasi-experimental literature on the efficacy of outreach by colleges, outreach programs can increase access to higher education among disadvantaged students when the program offers supplemental counseling or simplifies the college application process, but outreach programs are not effective when they merely provide general information (Herbaut \& Geven, in press).

Previous literature has also examined the effect of financial aid on the likelihood of college enrollment. Castleman and Long (2016) employed a regression discontinuity design and found that receiving the Florida Student Access Grant had a positive impact on students' likelihood of enrollment, which aligns with prior work showing the positive relationship between financial aid receipt and college enrollment (e.g., Fack \& Grenet, 2015; Goldrick-Rab et al., 2016. Bettinger (2015) also found that students who received needbased financial aid through the Ohio College Opportunity Grant initiative were less likely to drop out of college.

In a quasi-experimental study examining the impact of community college tuition discounts on student enrollment among recent high school graduates, Denning (2017) reported that community college enrollment increased by 5.1 percentage points for each $\$ 1,000$ reduction in tuition. Although prior work has shown that the Pell Grant receipt was not associated with an increase in college enrollment (Denning, Marx, \& Turner, 2017; Kane, 1995; Rubin, 2011), grants that supplement the Pell grant are more likely to positively influence 
college enrollment (e.g., Bettinger, 2015; Castleman \& Long, 2016). Richburg-Hayes et al. (2015) conducted a randomized controlled trial to examine the impact of a one-time, performance-based scholarship on students' likelihood of enrolling in college, finding that providing a $\$ 1,000$ performance-based scholarship increased students' likelihood of enrolling in college by 5 percentage points.

\section{Research Design}

This experimental study was conducted in collaboration with five high-enrollment community colleges located in the state of Florida. Each community college was selected due to its large enrollment size (roughly 64,000 students per community college) and diverse student body. We collaborated with each institution during the 2018-19 academic year to conduct the text message-based re-enrollment campaign.

\section{A. Data and Sample}

The text message-based re-enrollment campaign focused solely on former students who were identified as previously successful academically and eligible to re-enroll at their prior community college. To be included in our sample and eligible for treatment, former students were required to meet our agreed-upon criteria of 30 accrued credit hours, a 2.0 GPA or better, and no behavioral or financial holds that would prevent the former student from being allowed to re-enroll in college. We worked directly with the participating community colleges to further restrict our sample to former students who were enrolled previously in degreeseeking programs but stopped enrolling in courses within the past three years. Each participating community college provided administrative data files including all former students' demographic characteristics, academic information, and cell phone number.

We also partnered with a third-party vendor to ensure that all former students in our sample had an active cell phone number by removing any students who only had an inactive cell phone number on file. To ensure that we identified and removed any former students who had already re-enrolled or graduated from a different college or university, we matched student-level data obtained from each community college with data from the National Student Clearinghouse at the beginning of the project period and immediately before 
sending text messages. ${ }^{3}$ The residual sample of the study includes 27,028 former community college students. Before partnering with a text messaging platform to employ the interventions (described in detail directly below), we randomly assigned eligible students to a control group or one of two treatment groups.

Control Group: Students within the control group received no information through this experiment.

Information Only Treatment: Students within the "information only" treatment group received ten text messages directing them to re-enroll in college and visit our custom website to be able to streamline the reenrollment process, apply for financial aid, or contact an assigned advisor for assistance.

Information + One-Course Waiver Treatment: Students within the "information + one-course waiver" treatment group received the same information described in the above treatment and a one-course tuition waiver. This one-course tuition waiver could be a conditional waiver (additional aid received only if the student did not already have all coursework covered by financial aid) or unconditional waiver (refundable credit received even if all coursework is already fully covered by financial aid). Although we recommended that all participating community colleges offer an unconditional waiver, only two community colleges elected to offer the unconditional waiver and the remaining three offered the conditional waiver.

\section{B. Measures}

To examine the impact of each treatment on former students' likelihood of re-enrollment, we measure reenrollment as the primary outcome of interest and consider a host of demographic and academic characteristics to better understand our main and heterogeneous effects. First, we measure re-enrollment as a binary indicator capturing whether former students in our sample enrolled in at least one for-credit course at their prior institution during Summer 2018, Fall 2018, or Spring 2019. To further explore this outcome, we consider not only our main effects including the whole sample but also heterogeneous effects for the following subgroups of interest: individuals with lower GPAs (below 3.0), near completers (more than the median of

\footnotetext{
${ }^{3}$ The National Student Clearinghouse is a nongovernmental organization that serves as the nation's leading provider of enrollment and degree verification for colleges and universities. 
42 credit hours), low-income students, underrepresented minority students, and adult students (25 years of age or older).

To improve the precision of our empirical models, we include numerous covariates related to students' background characteristics, as outlined in Table 1. Finally, we include college fixed effects and specify additional models to consider whether each institution used a conditional or unconditional one-course tuition waiver. As noted previously, a conditional one-course tuition waiver allows students to waive tuition and fees for one course if at least one of their courses was not already covered by financial aid, whereas an unconditional one-course tuition waiver allows students to waive tuition and fees for one course regardless of the amount of financial aid they receive.

\section{Intervention Design}

Former students were randomly assigned to the control group, the information-only treatment, or the information and one-course waiver treatment. In May of 2018, we began our text message-based reenrollment campaign, which included targeted messaging to treated individuals immediately before matriculation deadlines for the Summer 2018, Fall 2018, and Spring 2019 semesters. The final text message was sent in December of 2018. The extent to which these former students had received any type of outreach prior to the intervention varied across colleges. Former students assigned to the control group did not receive any text messages, but they would be granted the same opportunities for advising and financial aid assistance as any other student if they initiated the original point of contact with the institution. After the introductory text message for treated individuals, text messages were sent every two to three weeks, with a total of ten text messages being sent to former students in either treatment group. Appendix A provides the content of each text message, which varied according to whether former students were assigned to the information-only or information and one-course waiver treatment group.

We reviewed the "business as usual" approach associated with re-enrolling at each community college and discovered that the standard process of re-enrolling was complex, challenging to navigate, and inconsistent across all five participating community colleges. To address these potential information barriers, 
we coordinated across all participating community colleges and created custom websites for each intervention at each community college to simplify the re-enrollment process (10 unique websites in total). For the information-only intervention, the custom website provided a single button to re-enroll immediately, a single button to apply for financial aid immediately, and the contact information of an assigned advisor-including the advisor's name, email, and phone number-for each former student. For the information and one-course waiver intervention, former students received the same information designed to simplify the re-enrollment process, but both the text messages and custom website clearly noted that they would receive a one-course tuition waiver upon re-enrolling. The one-course tuition waiver covered the equivalent of three credit hours of in-state tuition at the participating community college. Each text message, regardless of the intervention, prompted former students to visit their assigned custom website. If former students replied to any of our text messages, they received an automated reply directing them to their custom website. Appendix B shows example website for the information-only intervention and the information and one-course waiver intervention, respectively.

\section{Randomization and Baseline Equivalence}

Our study is based on a randomized block design, where we randomly assigned treatment status to former students within each of the five participating community colleges. Among the 27,028 former students in our sample, 9,010 were randomly assigned to the control group, 9,009 were randomly assigned to the information-only treatment group, and 9,009 were randomly assigned to the information and course waiver treatment group. In Table 1, we report basic descriptive statistics on students' demographics and prior academic circumstances. More specifically, we report means for the control group and differences between each treatment group (alongside standard errors). Unsurprisingly, we find little evidence of significant differences in observed means between the control group and treatment groups following the randomization, providing reassurance that we achieved baseline equivalence and the randomization was successful.

Among former community college students, only 41 percent of the control group is male, with equal proportions of men across the treatment groups. On average, individuals in our sample are older than 
traditional undergraduate students. The average age for individuals in the control group slightly exceeds 31 years. Our sample also demonstrates the racial diversity of American community colleges. Almost 24 percent of individuals in the control group are Black while Hispanics comprise 17 percent of the control group. Also, in the control group, more than 29 percent of individuals identify as multi-racial. About 13 percent of former students in the control group have limited English skills. Across every demographic attribute, we do no find significant differences in observed means between participants in the control group and those in either the information-only group or information and one-course tuition waiver group.

We also collected data on individual's academic performance and circumstances based on the last academic year they attended community college. For the control group, the average grade point average earned is nearly 2.8. The average number of credits accumulated is 45 . In general, we do not find any statistically significant differences between these measures of academic performance in the control group and the treatment groups, although there is one exception. Participants in the information-only group have marginally higher grade-point averages than those individuals in the control group. Nonetheless, this difference is very small and does not appear to be meaningful. As for the circumstances surrounding their most recent academic enrollment, for the control group, we find that only 12 percent of individuals enrolled full-time and that 20 percent of these individuals transferred to a community college from a different postsecondary institution. Lastly, it is notable that many individuals in our sample received some form of financial assistance when last attending college. In the control group, 49 percent of individuals received needbased aid. Broadly, we report no statistically significant differences between any academic circumstances in the control group and treatment groups.

\section{E. Empirical Strategy}

Since we are utilizing random assignment, we can measure the impact of the interventions by making simple comparisons of the outcomes of individuals assigned to either the information-only treatment or the combined information and tuition-waiver treatment to those individuals in our sample who were not treated. We can estimate the intent-to-treat (ITT) effects by using a linear probability model: 
(1) $y_{i j}=\beta_{0}+\beta_{1} I N F O_{i j}+\beta_{2} I N F O_{-} W A I V E R_{i j}+\beta_{3} X_{i j}+\theta_{j}+\varepsilon_{i j}$,

where $y_{i j}$ is an indicator equaling one or zero for whether individual $i$ who was formerly enrolled in college $j$ decides to re-enroll in community college. The variable $I N F O_{i j}$ is a treatment indicator that equals one if an individual is offered information on how to re-enroll at college $j$ and takes the value zero otherwise. The variable INFO_WAIVER $R_{i j}$ is also a treatment indicator that takes a value of one if an individual is offered both information on how to re-enroll and a financial incentive in the form of a one-course tuition waiver by college $j . \boldsymbol{X}_{i j}$ represents a vector of demographic variables and information on the academic performance and circumstances of individual $i$ who formerly attended community college $j$. We also include dummy variables for the last academic term in which each student enrolled. All covariates included in the model are represented in Table 1. Also, $\theta_{j}$ is a fixed effect for college $j$ and signifies the randomization was conducted within each community college. The error term is represented by $\varepsilon_{i j}$. Lastly, we use robust standard errors to account for heteroskedasticity induced from using linear probability models.

\section{Results}

\section{A. Estimated Effects of the Re-Enrollment Campaign}

Table 2 reports our main results for the estimated effects of the information-only treatment and the estimated effects of the bundled information nudge with financial incentives on community college reenrollment. We report the findings in separate columns based on the full sample of community colleges and whether a community college offered an unconditional or conditional tuition waiver. In the first column, we report results based on pooling individuals attending each of the community colleges. In the second column, we report results for the two community colleges that offered unconditional one-course tuition waivers. In the third column, we report results for the three community colleges that offered conditional one-course tuition waivers.

The first column reports findings for the full sample of all community colleges. As shown, the reenrollment rate for individuals in the control group is slightly more than 7 percent. For this sample, we find that the information-only treatment does not have an effect on re-enrollment but that the information nudge 
combined with the course tuition waiver has a significant impact on re-enrollment. Compared to the control group, individuals offered both information and one course waiver are 1.5 percentage points (or 21 percent) more likely to re-enroll. This estimated effect is statistically significant at the 1 percent level. The effect of the information-only treatment on re-enrollment is 0.5 percentage points and is not statistically significant. An F-test of the joint hypothesis for whether the estimated re-enrollment effect from receiving the information and one-course tuition waiver treatments is equal to the effect of receiving the information-only treatment can be rejected at the 5 percent level of significance.

In contrast to other colleges in our sample, two community colleges offered former students unconditional one-course tuition waivers if they re-enrolled. It is important to examine how students respond to this form of unrestricted financial incentives as compared to one-course tuition waivers that are conditional on the amount financial aid that students already receive. Similar to the above results, we find that information alone has essentially no effect on whether individuals re-enroll at institutions offering the unconditional onecourse tuition waiver. However, we uncover a relatively large effect from the combined treatment at these institutions. Specifically, offering information and an unconditional one-course tuition waiver increases reenrollment by 2.5 percentage points or 21 percent of the re-enrollment rate for the control group. The estimate is statistically significant at the 5 percent level. We can reject the hypothesis of equal treatment effects at the 1 percent level of significance. Along with the prior evidence on the full sample, this evidence suggests that information alone may not be sufficient to encourage former community college students to re-enroll.

Our main results also examine the treatment effects for individuals who were formerly enrolled at community colleges that provided conditional one-course tuition waivers. Students from these community colleges make up 77 percent of the sample. Unlike the previous evidence, our findings from this subsample suggest that the information-only treatment has a small statistically significant effect on re-enrollment, increasing re-enrollment by 0.7 percentage points, which is significant at the 10 percent level. For individuals from this group of colleges, we find that the combined information and one-course waiver treatment increases 
the likelihood of re-enrollment by 1.1 percentage points. For this subsample, we cannot reject the null hypothesis of equal treatment effects.

Although we report the main effects separately for community colleges that offer conditional or unconditional tuition waivers (see column 4 within Table 2), we also assess whether the treatment effects are in fact different depending on the type of one-course tuition waiver offered by the participating community colleges. To inform this hypothesis, we pool both samples of community colleges and include interaction terms that capture whether the treatment effects vary based upon whether a community college offered unconditional waivers. We find that each of these estimated interaction effects is not statistically significant. These findings suggest that the format of the one-course tuition waiver does not appear to matter and that we can focus on results from the pooled sample.

Finally, we examine the effects of each treatment on former students' likelihood to re-enroll in multiple courses or re-enroll as a full-time student (see Table 3). Although the information-only treatment has no impact on former students' likelihood of re-enrolling in more than one course or as a full-time student, the combined intervention including information and a one-course tuition waiver had a positive effect on both outcomes of interest. Specifically, the information and one-course waiver treatment increases the likelihood of re-enrolling in multiple courses by 0.9 percentage points. In addition, the combined intervention increases former students' likelihood of re-enrolling as a full-time student by 0.5 percentage points.

\section{B. Heterogeneous Effects}

The effects of the information-only treatment and combined information and one-course tuition waiver treatment may vary based upon certain observable characteristics of individuals and their academic circumstances. For all subgroups that we examined, we found little evidence that the information-only treatment has a statistically significant effect on re-enrollment. However, our findings do point to some evidence of heterogeneity for the effectiveness of the information and one-course tuition waiver treatment (see Table 4). For example, we find that the estimated effects of the information and course-waiver treatment are concentrated among individuals with lower GPAs. More specifically, for students holding a GPA less 
than 3.0, the intervention increases community college re-enrollment by 1.7 percentage points, while the estimated effect on individuals with higher GPAs is qualitatively smaller and not statistically significant.

Next, we aim to understand whether the effects vary based on the number of credits an individual accumulated previously. The median number of accumulated credits for students in our sample is 42 . We examine the effects on students who achieved more than 42 credits and conduct a separate analysis for individuals who achieved fewer credits. The effect of the information and one-course waiver treatment for individuals who accumulated fewer credits is very small and not statistically significant. However, the estimated effect on individuals who earned more than 42 credits is considerably larger. For these students, the combined intervention increases community college re-enrollment by 2.1 percentage points. ${ }^{4}$

The timing of when a student stops enrolling at a community college may play a critical role in determining whether that individual chooses to return. In fact, among former students in our control group, we observe that recent dropouts re-enroll at more than twice the rate of individuals who drop out earlier -11 percent versus 4 percent. We therefore examine whether the effects of the information and one-course tuition waiver treatment vary based on when individuals left community college. Both groups of former students who left community college during or since the Spring 2016 semester and former students who dropped out during the Fall 2016 semester or earlier are significantly affected by the combined intervention of simplified information and a one-course tuition waiver. However, the magnitude of the treatment effect on more recent dropouts is stronger than the effect on earlier dropouts.

The final subgroup analysis we conducted related to academic circumstances pertains to whether the individual was a low-income student (as indicated by receiving need-based aid). Almost half of all individuals in our sample received need-based aid when last enrolled. We examine whether the effect of the information and one-course tuition waiver treatment vary based upon whether an individual received need-based aid. Our findings are robust to whether or not someone was awarded need-based aid. For low-income individuals who

\footnotetext{
${ }^{4}$ In unreported results, we also estimated pooled models where we interacted an indicator for observable characteristics with the information and one-course waiver treatment. Across all subgroups examined, we only find statistically significant evidence that former students who have accumulated more credits are more affected than individuals who completed fewer credits.
} 
receive need-based aid, we find that the combined intervention of an information nudge and one-course tuition waiver significantly increases their likelihood of re-enrolling by 1.3 percentage points at the 5 percent level of significance. For individuals who did not receive need-based aid and may be more likely to be economically advantaged, we find that the information and one-course tuition waiver treatment significantly increases the likelihood of re-enrolling by 1.7 percentage points at a significance level of 1 percent.

Our study also examines whether treatment effects may differ based upon select demographic attributes. For this study, we investigate whether the treatment effects are significant for both Blacks and Hispanics and, separately, for non-Hispanic whites ${ }^{5}$. For both groups of individuals, the results are remarkably similar and both are statistically significant. The information and one-course tuition waiver treatment increases the likelihood of re-enrollment among Blacks or Hispanics by 1.7 percentage points. For individuals who are non-Hispanic white, we find that the estimated effect is 2.1 percentage points. We also examine whether our interventions may have differential effects based on whether someone is older or younger. For individuals 24 years and younger, we find that the information and one-course course waiver treatment has a small and statistically insignificant effect of 0.6 percentage points on re-enrollment. On the other hand, for older students, we show that the combined intervention increases the likelihood of reenrollment by 1.7 percentage points at the 1 percent level of significance.

\section{Discussion}

The majority of students who begin at a community college leave school without earning a degree. In response to high rates of student attrition, a growing number of community colleges have implemented reenrollment campaigns designed to encourage and potentially incentivize former students to return to college. This experimental study represents the first attempt to examine the causal impact of a low-touch re-enrollment campaign and provides evidence to show that the combined information and one-course tuition waiver treatment had a positive impact on former students' probability of re-enrollment. Through this targeted reenrollment campaign, we identify an intervention that increases former students' likelihood of re-enrollment

\footnotetext{
${ }^{5}$ Subgroup analyses for Black and Hispanic students and white students do not comprise the full analytic sample.
} 
in the aggregate and across multiple student subgroups, including low-income students, underrepresented minority students, adult students, and students with low GPAs.

Previous research has reported positive effects when examining the efficacy of localized text messagebased campaigns (Castleman \& Page, 2015; Castleman et al., 2014; Castleman et al., 2015), but a growing body of recent evidence has shown that informational nudges alone, when offered at a larger scale, do not appear to significantly improve the likelihood of college enrollment (e.g., Bird et al., 2019). Additional work has suggested that behavioral outreach programs can increase access to higher education among disadvantaged students when the program simplifies the college application process (Herbaut \& Geven, in press). However, we find little evidence suggesting that streamlining the re-enrollment process, without offering financial incentives, significantly impacts former students' likelihood of re-enrollment in the aggregate or across student subgroups.

This study offers clear and robust evidence of the positive impact of the information and one-course tuition waiver treatment on the likelihood of former students re-enrolling in college. For community colleges that may be finding limited success through letter-writing campaigns or third-party call centers, we show that interventions including both pertinent re-enrollment information and a one-course tuition waiver have a positive impact on the probability of former students returning to college. Given that a substantial number of postsecondary students leave college due to informational and financial barriers as opposed to their academic ability or classroom performance (e.g., Long, 2007), this study highlights the importance of interventions that not only simplify complex processes but also reduce the financial barriers facing community college students.

Because the provision of a one-course tuition waiver costs between $\$ 303$ and $\$ 354$ for participating community colleges, one potential concern may be that a former student will only return for a single course and not allow the institution to recoup course waiver costs and generate additional tuition revenue. We ran additional specifications to examine whether providing the course waiver can make financial sense for the institutions. For example, Table 3 shows that the informational nudge alone is unrelated to the likelihood of former students re-enrolling in more than one course, but the combination of the informational nudge and 
one-course tuition waiver led to a 16.4 percent increase in former students' likelihood of re-enrolling in more than one course and a 21.7 percent increase in the likelihood of non-completers returning as full-time students.

Although the combination of an informational nudge and one-course tuition waiver may represent a relatively affordable policy lever to foster re-enrollment among former community college students, further research is needed to better understand whether former students who re-enroll are also more likely to persist and ultimately complete their degree upon returning to college. Additional research is also needed to explore why community college dropouts decide to leave college in the first place and what can be done to prevent their initial departure and thereby enhance their likelihood of degree completion. 


\section{References}

Bailey, T., Jaggars, S. S., \& Jenkins, D. (2015). Redesigning America's community colleges. Cambridge, MA: Harvard University Press.

Barr, A., Bird, K., \& Castleman, B. L. (2019). The effect of reduced student loan borrowing on academic performance and default: Evidence from a loan counseling experiment. (EdWorkingPaper No. 1989). Retrieved from Annenberg Institute at Brown University:

http://www.edworkingpapers.com/ai19-89

Barr, A., \& Turner, S. (2018). A letter and encouragement: Does information increase postsecondary enrollment of UI recipients? American Economic Journal: Economic Policy, 10(3), 42-68.

Becker, G. S. (1962). Investment in human capital: A theoretical analysis. Journal of Political Economy, 70(5), 9-49.

Belfield, C. R., \& Bailey, T. (2011). The benefits of attending community college: A review of the evidence. Community College Review, 39(1), 46-68.

Bergman, P., Denning, J. T., \& Manoli, D. (2019). Is information enough? The effect of information about education tax benefits on student outcomes. Journal of Policy Analysis and Management, 38(3), 706-731.

Berkner, L., \& Choy, S. (2008). Descriptive summary of 2003-04 beginning postsecondary students: Three years later. Washington, DC: National Center for Education Statistics.

Bettinger, E. (2015). Need-based aid and college persistence: The effects of the Ohio College Opportunity Grant. Educational Evaluation and Policy Analysis, 37(1_suppl), 102S-119S.

Bettinger, E.P., Long, B.T., Oreopoulos, P., \& Sanbonmatsu, L. (2012). The role of application assistance and information in college decisions: Results from the H\&R Block FAFSA Experiment. The Quarterly Journal of Economics, 127(3), 1205-1242. 
Bird, K. A., Castleman, B. L., Denning, J. T., Goodman, J., Lamberton, C., \& Rosinger, K. O. (2019). Nudging at scale: Experimental evidence from FAFSA completion campaigns (No. w26158). National Bureau of Economic Research.

Castleman, B. L., \& Long, B. T. (2016). Looking beyond enrollment: The causal effect of need-based grants on college access, persistence, and graduation. Journal of Labor Economics, 34(4), 10231073.

Castleman, B. L., \& Page, L. C. (2015). Summer nudging: Can personalized text messages and peer mentor outreach increase college going among low-income high school graduates? Journal of Economic Behavior \& Organization, 115, 144-160.

Castleman, B. L., \& Page, L. C. (2016a). Freshman year financial aid nudges: An experiment to increase FAFSA renewal and college persistence. Journal of Human Resources, 51(2), 389-415.

Castleman, B. L., Page, L. C., \& Schooley, K. (2014). The forgotten summer: Mitigating summer attrition among college-intending, low-income high school graduates. Journal of Policy Analysis and Management, 33(2), 320-344.

Crosta, P. (2013). Characteristics of early community college dropouts. New York, NY: Columbia University Teachers College, Community College Research Center.

Denning, J. T. (2017). College on the cheap: Consequences of community college tuition reductions. American Economic Journal: Economic Policy, 9(2), 155-88.

Denning, J. T., Marx, B. M., \& Turner, L. J. (2019). ProPelled: The effects of grants on graduation, earnings, and welfare. American Economic Journal: Applied Economics, 11(3), 193-224.

DesJardins, S. L., \& Toutkoushian, R. K. (2005). Are students really rational? The development of rational thought and its application to student choice. In J. C. Smart (Ed.), Higher education: Handbook of theory and research. (Vol. 20, pp. 191-240). Dordrecht, Netherlands: Springer. 
Fack, G., \& Grenet, J. (2015). Improving college access and success for low-income students: Evidence from a large need-based grant program. American Economic Journal: Applied Economics, 7(2), 134.

Goldrick-Rab, S., Kelchen, R., Harris, D. N., \& Benson, J. (2016). Reducing income inequality in educational attainment: Experimental evidence on the impact of financial aid on college completion. American Journal of Sociology, 121(6), 1762-1817.

Herbaut, E., \& Geven, K. M. (2019). What works to reduce inequalities in higher education? A systematic review of the (quasi-)experimental literature on outreach and financial aid. Research in Social Stratification and Mobility.

Jepsen, C., Troske, K., \& Coomes, P. (2014). The labor-market returns to community college degrees, diplomas, and certificates. Journal of Labor Economics, 32(1), 95-121.

Inside Track (2019). Re-engage, re-enroll, and prepare former students to finish strong. Retrieved from http://info.insidetrack.com/re-engage_re-enroll_and_prepare_ps

Kahneman, D., \& Tversky, A. (1979). Prospect theory: An analysis of decision under risk. Econometrica, 47, 263- 291.

Kane, T. J. (1995). Rising public college tuition and college entry: How well do public subsidies promote access to college? (No. w5164). National Bureau of Economic Research.

Karlan, D., McConnell, M., Mullainathan, S., \& Zinman, J. (2016). Getting to the top of mind: How reminders increase saving. Management Science, 62, 3393-3672.

Lashure, F., Randall, S., \& Hinkle, H. (2019). The retention project and the investigation of a non-returning new student re-enrollment strategy. Strategic Enrollment Management Quarterly.

Levin, H. M. (1989). Mapping the economics of education: An introductory essay. Educational researcher, 18(4), 13-17.

Long, B. T. (2007). The contributions of economics to the study of college access and success. Teachers College Record, 109(10), 2367-2443. 
Meyer, K., \& Rosinger, K. O. (2019). Applying behavioral insights to improve postsecondary education outcomes: A review of Obama administration efforts and next steps under the Trump administration. Journal of Policy Analysis and Management, 38(2), 481-499.

Mincer, J. (1958). Investment in human capital and personal income distribution. The Journal of Political Economy, 66, 281-302.

Oreopoulos, P., \& Petronijevic, U. (2013). Making college worth it: A review of the returns to higher education. The Future of Children, 41-65.

Oreopoulos, P., \& Petronijevic, U. (2019). The remarkable unresponsiveness of college students to nudging and what we can learn from it (No. w26059). National Bureau of Economic Research.

Page, L. C., \& Gehlbach, H. (2017). How an artificially intelligent virtual assistant helps students navigate the road to college. AERA Open, 3(4), 1-12.

Rath, B., Rock, K., \& Laferriere, A. (2013). Pathways through college: Strategies for improving community college student success. Hartford, CT: Our Piece of the Pie.

Richburg-Hayes, L., Patel, R., Brock, T., de la Campa, E., Rudd, T., \& Valenzuela, I. (2015). Providing more cash for college: Interim findings from the performance-based scholarship demonstration in California. New York, NY: MDRC.

Ronco, S. L. (1994). Meandering ways: Studying student stopout with survival analysis. Association of Institutional Research.

Rouse, C. E. (1995). Democratization or diversion? The effect of community colleges on educational attainment. Journal of Business \& Economic Statistics, 13(2), 217-224.

Rubin, R. B. (2011). The pell and the poor: A regression-discontinuity analysis of on-time college enrollment. Research in Higher Education, 52(7), 675-692.

Schwartz, N. (2019). How colleges are bringing back stopped-out students. Education Dive. Retrieved from https://www.educationdive.com/news/how-colleges-are-bringing-back-stopped-outstudents/556706/. 
Scott-Clayton, J. E. (2017). Undergraduate financial aid in the United States. American Academy of Arts $\&$ Sciences.

Shapiro, D., Dundar, A., Huie, F., Wakhungu, P.K., Yuan, X., Nathan, A. \& Bhimdiwali, A. (2017). Completing College: A National View of Student Completion Rates. Herndon, VA: National Student Clearinghouse Research Center.

Stinebrickner, R., \& Stinebrickner, T. (2008). The effect of credit constraints on the college drop-out decision: A direct approach using a new panel study. American Economic Review, 98(5), 2163-84.

Thaler, R., \& Benartzi, S. (2004). Save more tomorrow: Using behavioral economics to increase employee saving. Journal of Political Economy, 112, 164-187.

Thaler, R. H., \& Sunstein, C. R. (2008). Nudge: Improving decisions about health, wealth, and happiness. New Haven, CT: Yale University Press.

Trostel, P., \& Chase, M. (2015). It's not just the money: The benefits of college education to individuals and to society. Lumina Issue Papers. 


\section{Table 1: Descriptive Statistics and Balance Tests}

\begin{tabular}{|c|c|c|c|c|c|}
\hline & $\begin{array}{c}\text { Control } \\
\text { mean } \\
(1)\end{array}$ & $\begin{array}{l}\text { Information vs. } \\
\text { control } \\
\text { (2) }\end{array}$ & $\begin{array}{c}\text { Info. \& one-course } \\
\text { waiver vs. control } \\
\text { (3) }\end{array}$ & $\begin{array}{c}\text { F-stat } \\
\text { (all=control) } \\
\text { (4) }\end{array}$ & $\begin{array}{c}\text { Observations } \\
\text { (5) }\end{array}$ \\
\hline \multicolumn{6}{|c|}{ Student Background Characteristics } \\
\hline Male & 0.414 & $\begin{array}{c}0.004 \\
(0.007)\end{array}$ & $\begin{array}{c}-0.001 \\
(0.007)\end{array}$ & $\begin{array}{c}0.248 \\
(0.780)\end{array}$ & 27028 \\
\hline Age & $\begin{array}{l}31.515 \\
(9.594)\end{array}$ & $\begin{array}{c}0.002 \\
(0.142)\end{array}$ & $\begin{array}{c}0.104 \\
(0.142)\end{array}$ & $\begin{array}{c}0.352 \\
(0.703)\end{array}$ & 27028 \\
\hline Black & 0.237 & $\begin{array}{c}0.004 \\
(0.006)\end{array}$ & $\begin{array}{c}0.004 \\
(0.006)\end{array}$ & $\begin{array}{c}0.276 \\
(0.759)\end{array}$ & 27028 \\
\hline Hispanic & 0.165 & $\begin{array}{c}-0.003 \\
(0.005)\end{array}$ & $\begin{array}{c}-0.002 \\
(0.005)\end{array}$ & $\begin{array}{c}0.188 \\
(0.829)\end{array}$ & 27028 \\
\hline Multi-racial & 0.294 & $\begin{array}{c}-0.002 \\
(0.006)\end{array}$ & $\begin{array}{c}-0.005 \\
(0.006)\end{array}$ & $\begin{array}{c}0.310 \\
(0.733)\end{array}$ & 27028 \\
\hline Other & 0.029 & $\begin{array}{c}-0.002 \\
(0.002)\end{array}$ & $\begin{array}{c}-0.003 \\
(0.002)\end{array}$ & $\begin{array}{c}0.752 \\
(0.471)\end{array}$ & 27028 \\
\hline Limited English & 0.127 & $\begin{array}{l}-0.003 \\
(0.005)\end{array}$ & $\begin{array}{c}-0.005 \\
(0.005)\end{array}$ & $\begin{array}{c}0.494 \\
(0.610)\end{array}$ & 27028 \\
\hline Grade Point Average & $\begin{array}{c}2.774 \\
(0.623)\end{array}$ & $\begin{array}{c}0.015^{*} \\
(0.009)\end{array}$ & $\begin{array}{c}0.002 \\
(0.009)\end{array}$ & $\begin{array}{c}1.793 \\
(0.166)\end{array}$ & 26551 \\
\hline Accumulated Credits & $\begin{array}{c}44.700 \\
(24.332)\end{array}$ & $\begin{array}{c}0.318 \\
(0.339)\end{array}$ & $\begin{array}{c}0.310 \\
(0.339)\end{array}$ & $\begin{array}{c}0.572 \\
(0.564)\end{array}$ & 27028 \\
\hline Full-Time & 0.121 & $\begin{array}{c}0.007 \\
(0.005)\end{array}$ & $\begin{array}{c}-0.004 \\
(0.005)\end{array}$ & $\begin{array}{c}2.397 \\
(0.091)\end{array}$ & 27028 \\
\hline Transfer Student & 0.203 & $\begin{array}{l}-0.006 \\
(0.005)\end{array}$ & $\begin{array}{c}-0.008 \\
(0.005)\end{array}$ & $\begin{array}{c}1.296 \\
(0.274)\end{array}$ & 27028 \\
\hline Need-Based Aid Recipient & 0.485 & $\begin{array}{c}0.006 \\
(0.007)\end{array}$ & $\begin{array}{c}-0.005 \\
(0.007)\end{array}$ & $\begin{array}{c}1.205 \\
(0.300)\end{array}$ & 27028 \\
\hline Grade Point Average Missing & 0.018 & $\begin{array}{c}-0.001 \\
0.002\end{array}$ & $\begin{array}{c}-0.001 \\
(0.002)\end{array}$ & $\begin{array}{c}0.080 \\
(0.923)\end{array}$ & 27028 \\
\hline
\end{tabular}

Notes: Standard deviations are reported in parentheses in column (1). Standard errors are shown in parentheses in columns (2) and (3). $p$-values for $F$-tests are reported in parentheses in column (4). The number of non-missing observations are reported in column (5). *** Significant at 1 percent level; ** 5 percent level; * 10 percent level. 
Table 2: Estimated Effects of Re-Enrollment Campaign

Samples:

\section{Type of Waiver:}

\begin{tabular}{cccc}
\hline All & Unconditional & Conditional & All \\
Institutions & Waivers & Waivers & Institutions \\
\hline
\end{tabular}

Information

0.005

$-0.002$

$0.007^{*}$

0.0065

$(0.004)$

$(0.010)$

$(0.004)$

$(0.0040)$

Information and one-course

$0.015 * * *$

$0.025^{* *}$

$0.011 * * *$

$0.011 * * *$

waiver

$(0.004)$

(0.010)

$(0.004)$

(0.003)

Information * Unconditional

$-0.008$

waiver offered

Information and one-course

0.014

waiver * Unconditional waiver

$(0.011)$

Control mean

0.071

0.119

0.057

0.071

$\mathrm{R}^{2}$

0.052

0.071

0.029

0.052

$p$-value (F-test of equality of

0.012

treatment effects)

$p$-value (F-test of joint

0.116

significance of interaction effects)

$\mathrm{N}$

27,028

6,130

20,898

27,028

Notes: Coefficients reported are from linear probability models of the estimated effects of information and financial nudges on re-enrollment of college dropouts, controlling for baseline covariates and college-level fixed effects. Baseline covariates are those variables included in Table 1. Observations with missing grade point average are coded with the median values and we include an indicator for covariate missingness. Robust standard errors are reported in parentheses. ${ }^{* * *}$ Significant at 1 percent level; ** 5 percent level; * 10 percent level. 
Table 3: Estimated Effects of Re-Enrollment Campaign, More than 3 Credits \& Full-Time Enrollment

\begin{tabular}{|c|c|c|}
\hline \multirow{2}{*}{ Type of Waiver: } & \multirow[b]{2}{*}{ Re-Enroll $>3$ Credits } & \multirow[b]{2}{*}{ Re-Enroll $\geq 12$ Credits } \\
\hline & & \\
\hline \multirow[t]{2}{*}{ Information } & 0.005 & 0.002 \\
\hline & $(0.003)$ & $(0.002)$ \\
\hline Information and one-course & $0.009 * * *$ & $0.005 * *$ \\
\hline tuition waiver & $(0.003)$ & $(0.002)$ \\
\hline Control mean & 0.055 & 0.023 \\
\hline $\mathrm{R}^{2}$ & 0.045 & 0.029 \\
\hline $\begin{array}{l}p \text {-value (F-test of equality } \\
\text { of treatment effects) }\end{array}$ & 0.301 & 0.181 \\
\hline $\mathrm{N}$ & 27,028 & 27,028 \\
\hline
\end{tabular}


Table 4: Estimated Effects of Re-Enrollment Campaign by Academic Performance and Demographics

\begin{tabular}{|c|c|c|c|c|c|c|}
\hline & \multicolumn{2}{|c|}{ Grade Point Average } & \multicolumn{2}{|c|}{ Accumulated Credits } & \multicolumn{2}{|c|}{ Semesters Since Dropped Out } \\
\hline & $\mathrm{GPA}<3.0$ & $\mathrm{GPA} \geq 3.0$ & Accum. Credits $\leq 42$ & Accum. Credits $>42$ & Dropout $\leq$ Fall 2016 & Dropout $\geq$ Spring 2016 \\
\hline Information & $\begin{array}{c}0.006 \\
(0.005)\end{array}$ & $\begin{array}{c}0.004 \\
(0.007)\end{array}$ & $\begin{array}{c}0.002 \\
(0.005)\end{array}$ & $\begin{array}{c}0.008 \\
(0.005)\end{array}$ & $\begin{array}{c}0.001 \\
(0.004)\end{array}$ & $\begin{array}{r}0.010 \\
(0.020)\end{array}$ \\
\hline $\begin{array}{l}\text { Information \& one-course } \\
\text { waiver }\end{array}$ & $\begin{array}{l}0.017^{* * *} \\
(0.005)\end{array}$ & $\begin{array}{c}0.010 \\
(0.007)\end{array}$ & $\begin{array}{c}0.008 \\
(0.006)\end{array}$ & $\begin{array}{l}0.021^{* * *} \\
(0.005)\end{array}$ & $\begin{array}{c}0.011^{* * *} \\
(0.004)\end{array}$ & $\begin{array}{c}0.020^{* * *} \\
(0.008)\end{array}$ \\
\hline Control mean & 0.067 & 0.081 & 0.077 & 0.065 & 0.042 & 0.112 \\
\hline \multirow[t]{3}{*}{$\mathrm{N}$} & 16,899 & 9,651 & 13,671 & 13,357 & 16,050 & 10,978 \\
\hline & \multicolumn{2}{|c|}{ Age } & \multicolumn{2}{|c|}{ Race / Ethnicity } & \multicolumn{2}{|c|}{ Economic Status } \\
\hline & Age $\leq 24$ & Age $\geq 25$ & Black or Hispanic & non-Hispanic white & Low-Income & Not Low-Income \\
\hline Information & $\begin{array}{c}0.011 \\
(0.009)\end{array}$ & $\begin{array}{c}0.002 \\
(0.004)\end{array}$ & $\begin{array}{c}0.003 \\
(0.006)\end{array}$ & $\begin{array}{c}0.011 \\
(0.008)\end{array}$ & $\begin{array}{c}0.005 \\
(0.005)\end{array}$ & $\begin{array}{r}0.004 \\
(0.005)\end{array}$ \\
\hline $\begin{array}{l}\text { Information \& one-course } \\
\text { waiver }\end{array}$ & $\begin{array}{c}0.006 \\
(0.009)\end{array}$ & $\begin{array}{l}0.017 * * * \\
(0.004)\end{array}$ & $\begin{array}{l}0.017^{* * *} \\
(0.006)\end{array}$ & $\begin{array}{l}0.021^{* * *} \\
(0.008)\end{array}$ & $\begin{array}{l}0.012^{* *} \\
(0.006)\end{array}$ & $\begin{array}{l}0.017 * * * \\
(0.005)\end{array}$ \\
\hline Control mean & 0.113 & 0.057 & 0.072 & 0.070 & 0.070 & 0.072 \\
\hline $\mathrm{N}$ & 6,752 & 20,276 & 10,883 & 6,257 & 13,121 & 13,907 \\
\hline
\end{tabular}

Notes: Coefficients reported are from linear probability models of the estimated effects of information and financial nudges on re-enrollment of college dropouts, controlling for baseline covariates and college-level fixed effects. Baseline covariates are those variables included in Table 1. Observations with missing grade point average are coded with median values and we include an indicator for missing GPA. Robust standard errors are reported in parentheses. $* * *$ Significant at 1 percent level; ** 5 percent level; * 10 percent level. 
Appendix A. Text Messages Sent to Former Community College Students

\begin{tabular}{|c|c|c|c|}
\hline Message & Info & Conditional Waiver & Unconditional Waiver \\
\hline 1 & $\begin{array}{l}\text { Palm Beach State } \\
\text { College (PBSC) wants } \\
\text { you back! We have } \\
\text { simplified the } \\
\text { enrollment process. Go } \\
\text { to [web link for info } \\
\text { site.] for more info. } \\
\text { Reply stop to stop }\end{array}$ & $\begin{array}{l}\text { Palm Beach State } \\
\text { College (PBSC) wants } \\
\text { you back! We will cover } \\
\text { the tuition for your next } \\
\text { course. See how at [link } \\
\text { to waiver website] Reply } \\
\text { stop to stop }\end{array}$ & $\begin{array}{l}\text { Hillsborough Community } \\
\text { College (HCC) wants } \\
\text { you back! We will cover } \\
\text { the tuition for your next } \\
\text { course. See how at [link } \\
\text { to waiver website] Reply } \\
\text { stop to stop }\end{array}$ \\
\hline 2 & $\begin{array}{l}\text { You are so close to } \\
\text { finishing your degree! } \\
\text { Let Palm Beach State } \\
\text { College help you reach } \\
\text { your goals. Learn more } \\
\text { at [web link for info } \\
\text { site.] Reply stop to stop }\end{array}$ & $\begin{array}{l}\text { If financial aid does not } \\
\text { already cover your next } \\
\text { course, PBSC will waive } \\
\text { the tuition for that course. } \\
\text { Learn more at [link to } \\
\text { waiver website] Reply } \\
\text { stop to stop }\end{array}$ & $\begin{array}{l}\text { Need help paying for } \\
\text { your degree? HCC can } \\
\text { help you apply for } \\
\text { financial aid (FAFSA). } \\
\text { See how at [link to } \\
\text { waiver website] Reply } \\
\text { stop to stop }\end{array}$ \\
\hline 3 & $\begin{array}{l}\text { Need help paying for } \\
\text { your degree? Palm } \\
\text { Beach State College } \\
\text { can help you apply for } \\
\text { financial aid (FAFSA). } \\
\text { See how at [web link } \\
\text { for info site.] Reply } \\
\text { stop to stop }\end{array}$ & $\begin{array}{l}\text { Need help paying for } \\
\text { your degree? Palm Beach } \\
\text { State College can help } \\
\text { you apply for financial } \\
\text { aid (FAFSA). See how at } \\
\text { [link to waiver } \\
\text { website] Reply stop to } \\
\text { stop }\end{array}$ & $\begin{array}{l}\text { Do not miss this special } \\
\text { offer to enroll in your } \\
\text { next course at HCC for } \\
\text { free. Learn more at [link } \\
\text { to waiver website] Reply } \\
\text { stop to stop }\end{array}$ \\
\hline 4 & $\begin{array}{l}\text { Any questions about } \\
\text { registering for classes? } \\
\text { PBSC can offer } \\
\text { advising or enrollment } \\
\text { assistance. More info } \\
\text { @ [web link for info } \\
\text { site.] Reply stop to stop }\end{array}$ & $\begin{array}{l}\text { Any questions about } \\
\text { registering using your } \\
\text { tuition waiver? PBSC can } \\
\text { offer advising or } \\
\text { enrollment assistance. } \\
\text { More info @ [link to } \\
\text { waiver website] Reply } \\
\text { stop to stop }\end{array}$ & $\begin{array}{l}\text { Any questions about } \\
\text { registering using your } \\
\text { tuition waiver? HCC can } \\
\text { offer advising or } \\
\text { enrollment assistance. } \\
\text { More info @ [link to } \\
\text { waiver website] Reply } \\
\text { stop to stop }\end{array}$ \\
\hline 5 & $\begin{array}{l}\text { It is not too late to } \\
\text { register for classes! The } \\
\text { fall semester at PBSC } \\
\text { begins on August } 23 \text {. } \\
\text { Learn more @ [web } \\
\text { link for info } \\
\text { site.] Reply stop to stop }\end{array}$ & $\begin{array}{l}\text { It is not too late to } \\
\text { register for classes! The } \\
\text { fall semester at PBSC } \\
\text { begins on August } 23 \text {. } \\
\text { Claim your tuition waiver } \\
\text { @ [link to waiver } \\
\text { website] Reply stop to } \\
\text { stop }\end{array}$ & $\begin{array}{l}\text { It is not too late to } \\
\text { register for classes! The } \\
\text { fall semester at HCC } \\
\text { begins on August } 20 \text {. } \\
\text { Claim your tuition waiver } \\
\text { @ [link to waiver } \\
\text { website] Reply stop to } \\
\text { stop }\end{array}$ \\
\hline
\end{tabular}




\begin{tabular}{|c|c|c|c|}
\hline 6 & $\begin{array}{l}\text { You still have time to } \\
\text { register! PBSC offers } \\
\text { flexible online and } \\
\text { night classes to fit your } \\
\text { schedule. Get started @ } \\
\text { [web link for info } \\
\text { site.] Reply stop to stop }\end{array}$ & $\begin{array}{l}\text { You still have time to } \\
\text { register! PBSC offers } \\
\text { flexible online and night } \\
\text { classes to fit your } \\
\text { schedule. Get started } \\
\text { @ [link to waiver } \\
\text { website] Reply stop to } \\
\text { stop }\end{array}$ & $\begin{array}{l}\text { You still have time to } \\
\text { register! HCC offers } \\
\text { flexible online and night } \\
\text { classes to fit your } \\
\text { schedule. Get started } \\
\text { @ [link to waiver } \\
\text { website] Reply stop to } \\
\text { stop }\end{array}$ \\
\hline 7 & $\begin{array}{l}\text { Palm Beach State } \\
\text { College wants you } \\
\text { back! Spring } \\
\text { registration is now } \\
\text { open. Go to [web link } \\
\text { for info site.] for more } \\
\text { info. Reply stop to stop }\end{array}$ & $\begin{array}{l}\text { Spring registration is now } \\
\text { open! Palm Beach State } \\
\text { College will cover the } \\
\text { tuition for your next } \\
\text { course. See how at [link } \\
\text { to waiver website] Reply } \\
\text { stop to stop }\end{array}$ & $\begin{array}{l}\text { Spring registration at is } \\
\text { about to begin! } \\
\text { Hillsborough CC will } \\
\text { cover the tuition for your } \\
\text { next course. See how at } \\
\text { [link to waiver website] } \\
\text { Reply stop to stop }\end{array}$ \\
\hline 8 & $\begin{array}{l}\text { Need help paying for } \\
\text { your degree? Palm } \\
\text { Beach State College } \\
\text { can help you apply for } \\
\text { financial aid (FAFSA). } \\
\text { See how at [web link } \\
\text { for info site.] Reply } \\
\text { stop to stop }\end{array}$ & $\begin{array}{l}\text { Need help paying for } \\
\text { your degree? PBSC will } \\
\text { cover your next course } \\
\text { and help you apply for } \\
\text { financial aid. See how at } \\
\text { [the waiver site } \\
\text { link.] Reply stop to stop }\end{array}$ & $\begin{array}{l}\text { Need help paying for } \\
\text { your degree? HCC will } \\
\text { cover your next course } \\
\text { and help you apply for } \\
\text { financial aid. See how } \\
\text { at [the waiver site link.] } \\
\text { Reply stop to stop }\end{array}$ \\
\hline 9 & $\begin{array}{l}\text { It is not too late to } \\
\text { register for classes! The } \\
\text { spring semester at } \\
\text { PBSC begins on } \\
\text { January 4. Learn more } \\
\text { @ [web link for info } \\
\text { site.] Reply stop to stop }\end{array}$ & $\begin{array}{l}\text { It is not too late to } \\
\text { register for classes! The } \\
\text { spring semester at PBSC } \\
\text { begins on January } 4 \text {. } \\
\text { Claim your tuition waiver } \\
\text { @ [the waiver site } \\
\text { link.] Reply stop to stop }\end{array}$ & $\begin{array}{l}\text { It is not too late to } \\
\text { register for classes! The } \\
\text { spring semester at HCC } \\
\text { begins on January } 7 . \\
\text { Claim your tuition waiver } \\
\text { @ [the waiver site link.] } \\
\text { Reply stop to stop }\end{array}$ \\
\hline 10 & $\begin{array}{l}\text { This is your final } \\
\text { reminder to register for } \\
\text { classes at PBSC for the } \\
\text { Spring semester. } \\
\text { Contact your advisor at } \\
\text { [web link for info } \\
\text { site.] Reply stop to stop }\end{array}$ & $\begin{array}{l}\text { This is your final } \\
\text { reminder to claim your } \\
\text { tuition waiver at PBSC } \\
\text { for the Spring semester. } \\
\text { Contact your advisor } \\
\text { at [the waiver site } \\
\text { link.] Reply stop to stop }\end{array}$ & $\begin{array}{l}\text { This is your final } \\
\text { reminder to claim your } \\
\text { tuition waiver at HCC for } \\
\text { the Spring semester. } \\
\text { Contact your advisor } \\
\text { at [the waiver site link.] } \\
\text { Reply stop to stop }\end{array}$ \\
\hline
\end{tabular}




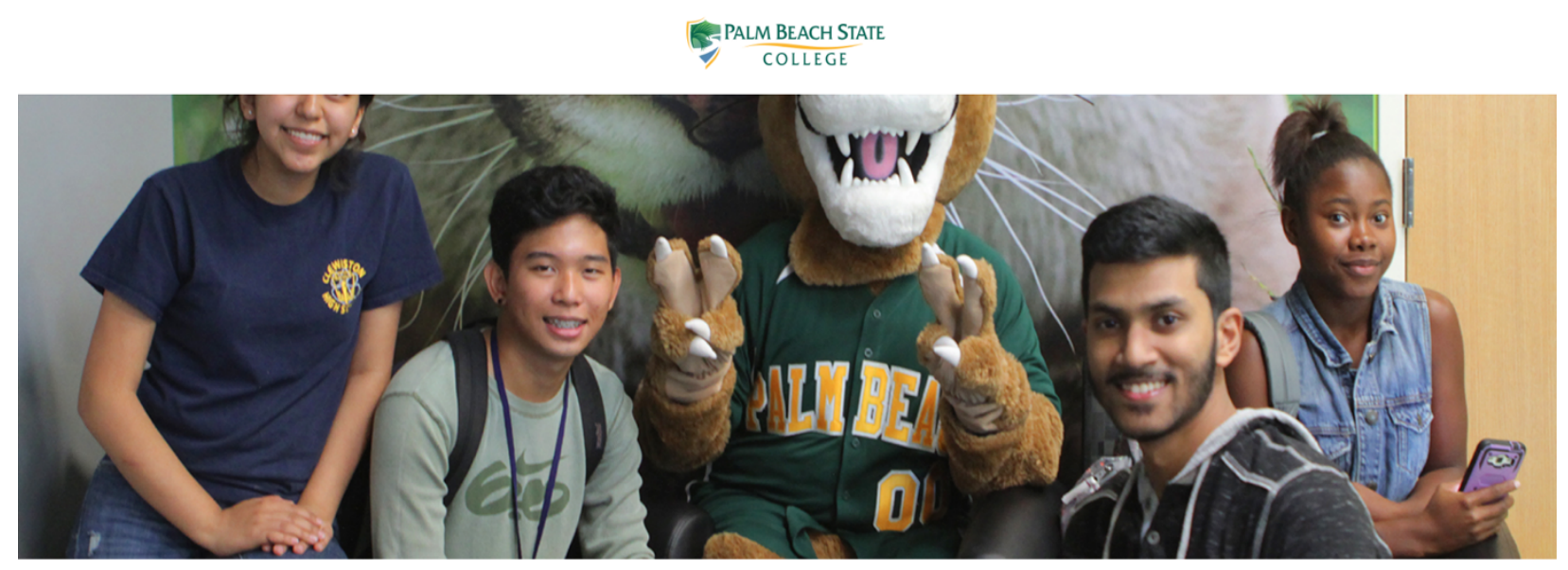

Congratulations on taking your first steps back to college!

Youve been contacted because you've made significant progress toward your degree and remain in good academic standing with Palm Beach State College.

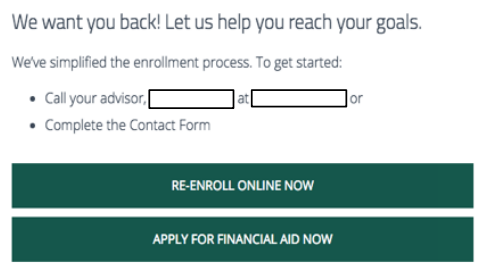

Need help? Contact us today!

Your Name

Preferred Contact Method

$\square$ Phone $\square$ Email

Your Email

Phone

Questions or Comments?
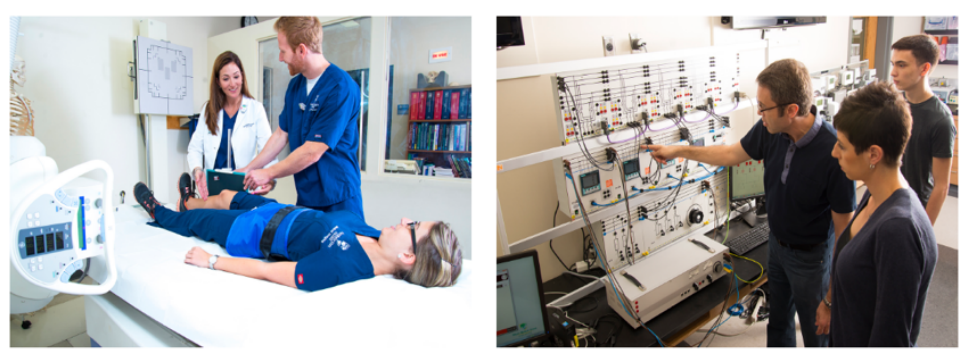

Resources

Contact Advisor

- Re-enrollment Steps

- PantherWeb Student Portal

To contact admissions, please email or call

- Course Schedule 


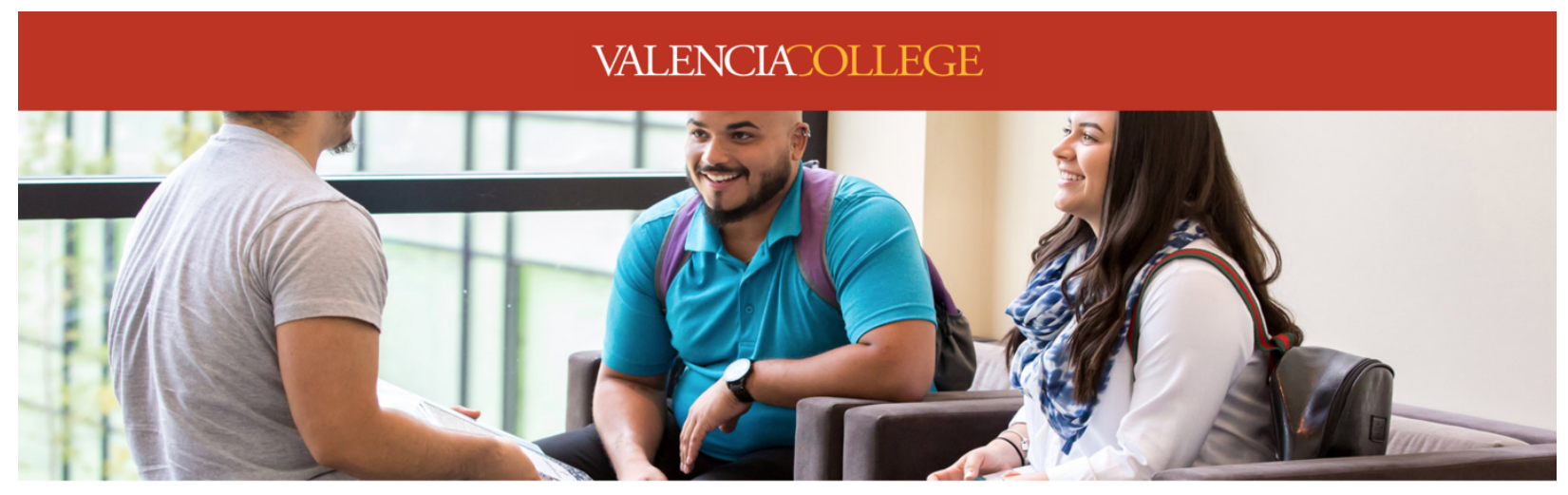

Congratulations on taking your first steps back to college!

You've been contacted because you've made significant progress toward your degree and remain in good academic standing with Valencia College. We have already waived your re-enrollment fees!

\section{Tuition Waiver - Special Offer}

By receiving our text message, you are eligible to enroll in your next course for free. Please contact your advisor, $\square$ to receive your free course waiver.

Please remember to apply for financial aid to see if you can receive additional funding.

We want you back! Let us help you reach your goals

We've simplified the enrollment process. To get started:

- Call your advisor, $\square$ at $\square$, or

- Complete the Contact Form
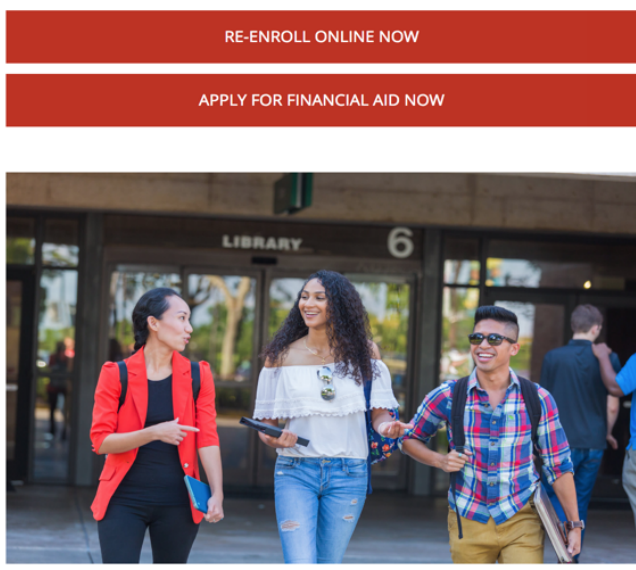

Resources

- Re-enrollment Steps

- Atlas Student Portal

- Course Schedule

Contact Advisor

\section{Need help? Contact us today!}

Your Name

Preferred Contact Method

$\checkmark$ Phone Email

Your Email

Phone

Questions or Comments?

SEND

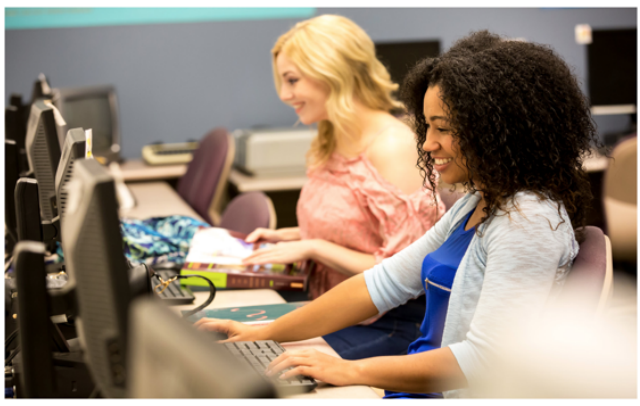

VALENCIACOLLEGE

To contact admissions, please email us or call $\square$ at 
Appendix C: The Relationship between Re-Enrollment and Academic Performance and Demographics

\begin{tabular}{|c|c|}
\hline & Re-Enrolled \\
\hline Male & $\begin{array}{l}-0.0095^{*} \\
(0.0055)\end{array}$ \\
\hline Age (years) & $\begin{array}{c}-0.0017 * * * \\
(0.0003)\end{array}$ \\
\hline Limited English Proficiency & $\begin{array}{l}-0.0132 * \\
(0.0078)\end{array}$ \\
\hline Black & $\begin{array}{c}0.0271 * * * \\
(0.0082)\end{array}$ \\
\hline Hispanic & $\begin{array}{c}0.0118 \\
(0.0088)\end{array}$ \\
\hline Multi-Racial & $\begin{array}{c}0.0174 * * \\
(0.0081)\end{array}$ \\
\hline Other Race & $\begin{array}{l}0.0368 * \\
(0.0195)\end{array}$ \\
\hline Grade Point Average & $\begin{array}{l}0.0101 * * \\
(0.0044)\end{array}$ \\
\hline Full-Time & $\begin{array}{c}0.0029 \\
(0.0089)\end{array}$ \\
\hline Transfer Credits & $\begin{array}{l}-0.0114 \\
(0.0074)\end{array}$ \\
\hline Need-Based Aid Recipient & $\begin{array}{c}0.0075 \\
(0.0059)\end{array}$ \\
\hline Accumulated Credits & $\begin{array}{l}-0.0000 \\
(0.0001)\end{array}$ \\
\hline Grade Point Average Missing & $\begin{array}{r}-0.0275 * * \\
(0.0137)\end{array}$ \\
\hline Constant & $\begin{array}{c}0.2848 * * * \\
(0.0382)\end{array}$ \\
\hline $\begin{array}{l}\text { Observations } \\
\text { R-squared }\end{array}$ & $\begin{array}{c}9,008 \\
0.0493\end{array}$ \\
\hline
\end{tabular}

Notes: The table reports results for a model that regresses an indicator for reenrollment on covariates for academic circumstances and demographic attributes of former students assigned to the control group. Robust standard errors are reported in parentheses. $* * * \mathrm{p}<0.01, * * \mathrm{p}<0.05, * \mathrm{p}<0.1$ 
Appendix D: Estimated Effects of Re-Enrollment Campaign for Different Specifications

\begin{tabular}{|c|c|c|c|c|c|}
\hline Type of Waiver: & \multicolumn{5}{|c|}{ All Institutions } \\
\hline \multirow[t]{2}{*}{ Information } & 0.005 & 0.005 & 0.005 & 0.005 & 0.005 \\
\hline & $(0.004)$ & $(0.004)$ & $(0.004)$ & $(0.004)$ & $(0.004)$ \\
\hline $\begin{array}{l}\text { Information and one-course } \\
\text { waiver }\end{array}$ & $\begin{array}{l}0.015^{* * *} \\
(0.004)\end{array}$ & $\begin{array}{l}0.015^{* * *} \\
(0.004)\end{array}$ & $\begin{array}{l}0.015^{* * *} \\
(0.004)\end{array}$ & $\begin{array}{l}0.014 * * * \\
(0.004)\end{array}$ & $\begin{array}{l}0.015 * * * \\
(0.004)\end{array}$ \\
\hline Control mean & 0.071 & & & & \\
\hline $\mathrm{R}^{2}$ & 0.001 & 0.009 & 0.011 & 0.041 & 0.052 \\
\hline Demographic controls & & $\mathrm{x}$ & $\mathrm{x}$ & $\mathrm{x}$ & $\mathrm{x}$ \\
\hline Academic background controls & & & $\mathrm{x}$ & $\mathrm{x}$ & $\mathrm{x}$ \\
\hline Last term enrolled & & & & $\mathrm{x}$ & $\mathrm{x}$ \\
\hline College-level fixed effects & & & & & $\mathrm{x}$ \\
\hline $\mathrm{N}$ & 27,028 & 27,028 & 27,028 & 27,028 & 27,028 \\
\hline
\end{tabular}

